\title{
Stability of Three Different Galenic Liquid Formulations Compounded from Tablet Containing Glibenclamide
} \author{
Giorgio Gioventù ${ }^{5}$ and Claudio Tubili ${ }^{1}$ \\ ${ }^{1}$ UOS di Diabetologia Con DH, Az. Osp. "S. Camillo - Forlanini", Roma, Italy \\ ${ }^{2}$ Aurelia Hospital, Roma, Italy \\ ${ }^{3}$ Farmacista Territoriale, Frosinone, Italy \\ ${ }^{4}$ Laboratorio Regionale Controllo Qualità, Ancona, Italy \\ ${ }^{5}$ Farmacista Territoriale, Fermo, Italy
}

Ugo Di Folco ${ }^{1, *}$, Daniela De Falco ${ }^{2}$, Fabio Marcucci ${ }^{3}$, Graziella Nobili ${ }^{3}$, Vincenzo Moretti ${ }^{4}$

\begin{abstract}
The suspensions of sulfonylurea glyburide (glibenclamide) are compounded extemporaneously for patients suffering from transitional and Permanent Neonatal Diabetes mellitus (PND). The purpose of this study is to compare the stability of three different galenic liquid formulations compounded from tablet containing glibenclamide. The samples were stored at refrigerated $\left(2-8^{\circ} \mathrm{C}\right)$ and room temperature and analyzed at different times. All formulations analysed are stable for at least 90 days, but only two guarantee the administration responding to prescription, especially when it comes to giving dosages very small.
\end{abstract}

Keywords: Glibenclamide, sulphonylurea, insulin, neonatal diabetes, formulation.

\section{INTRODUCTION}

The glibenclamide, a sulphonylurea, comes as a white crystalline powder, insoluble in water and sparingly soluble in alcohol and methanol. His pharmacological action take place in the short term and long-term. In the first phase of treatment the drug increases very quickly insulin secretion from pancreatic beta cells. Long-term action the main tasks are to intensify the action of insulin in the peripheral tissues. It is therefore used to treat type 2 diabetes and PND. The PND occurs typically in the first months of life and needs insulin treatment. In recent years has been discovered the connection between PND and the mutation of a gene affecting potassium channels KIR 6.2 of pancreatic beta cells [1-5] (Figure 1).

It was discovered that glibenclamide, used to treat type 2 diabetes, could also work to secrete insulin at children with mutation of KIR channels. PND by KIR gene mutation [6-9] represents a model of high importance given the opportunity to treat patients with oral hypoglycemic agents otherwise condemned to practice insulin for life. We have studied the stability of three formulations normally used in Italian paediatric hospital compounded from tablets; they are called Formulation A, Formulation B and Formulation $\mathrm{C}$. The compositions are reported below:

*Address corresponding to this author at the UOS di Diabetologia Con DH, Az. Osp. "S. Camillo - Forlanini", Roma, Italy; Tel: 3286618753; Fax: 077679264; E-mail: difugo@libero.it
A formulation: suspension of glibenclamide 0,1 $\mathrm{mg} / \mathrm{ml}$

$\begin{array}{ll}\text { Gliben or Euglucon } 5 \mathrm{mg} \text { tablets } & 2 \text { tablets } \\ \text { Glycerol } & \mathrm{g} 10 \\ \text { Sorbitol } & \mathrm{g} 9 \\ \text { Sodium Saccharine } & \mathrm{g} 0.1 \\ \text { Xanthan Gum } & \mathrm{g} 1 \\ \text { Raspberry liquid aroma 1x400 } & \mathrm{g} 0,6 \\ \text { Citric acid monohydrate } & \mathrm{g} 0,09 \\ \text { Sodium Citrate } & \mathrm{g} 0.18 \\ \text { Sodium Nipagina } & \mathrm{g} 0,08 \\ \text { Potassium Sorbate } & \mathrm{g} 0.1 \\ \text { Purified water } & \mathrm{g} 78.85\end{array}$

\section{B formulation: Suspension Glibenclamide $5 \mathrm{mg} / \mathrm{ml}$}

Euglucon or Gliben $5 \mathrm{mg}$ tablets

150 tablets

Water for injections

$140 \mathrm{ml}$

\section{C formulation: suspension of Glibenclamide 0,2 $\mathrm{mg} / \mathrm{ml}$}

$\begin{array}{ll}\text { Euglucon or Gliben } 5 \mathrm{mg} \text { tablets } & 4 \text { tablets } \\ \text { Ora-Sweet SF* } & 100 \mathrm{ml}\end{array}$

Formulations differ for glibenclamide concentration and excipients. The concentration of sulfonylurea 


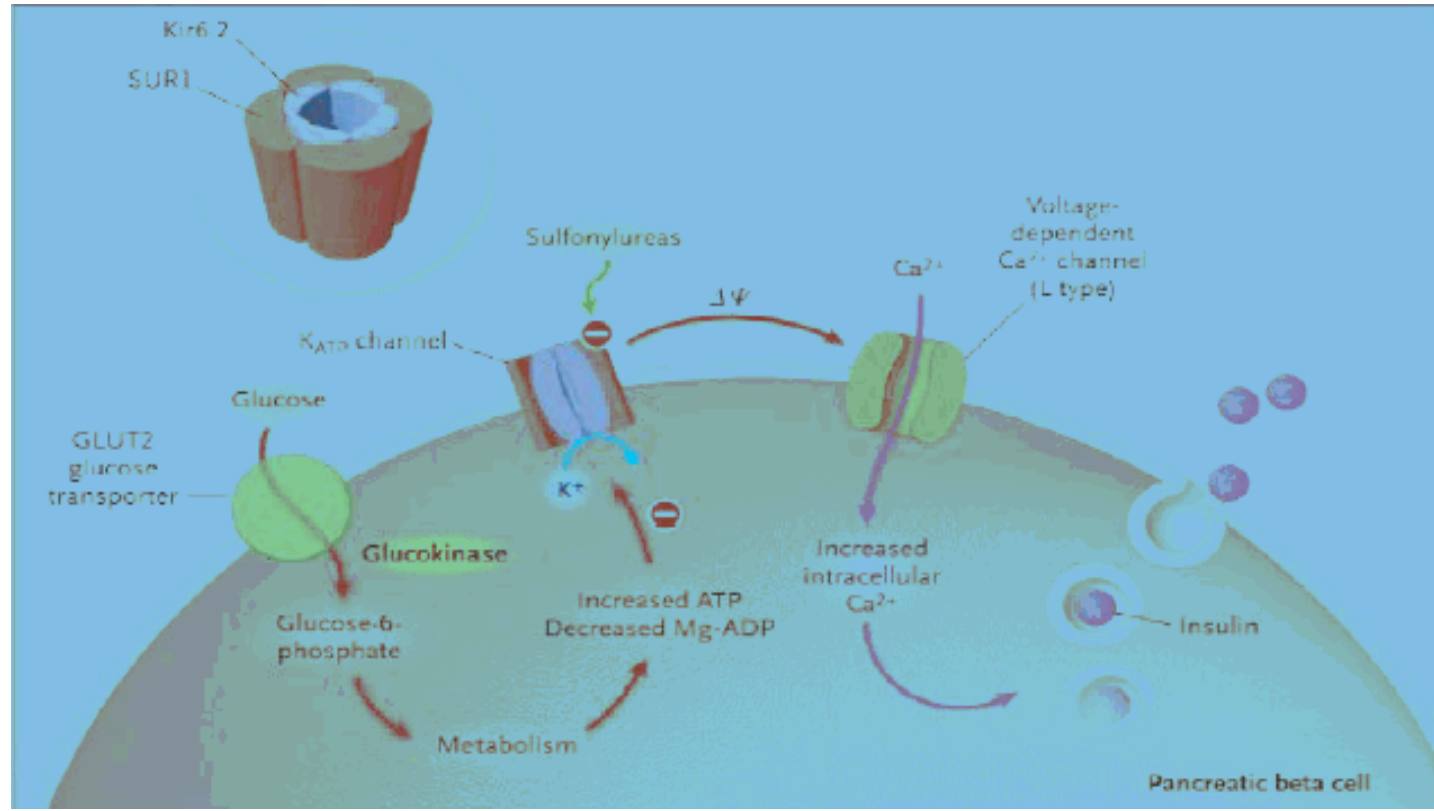

Figure 1: Schematic representation of the pancreatic beta cell.

Table 1: The Main Features and Differences of Formulations

\begin{tabular}{|c|c|c|c|}
\hline & Formulation A & Formulation B & Formulation C \\
\hline Concentration(mg/ml) & $0,1 \mathrm{mg} / \mathrm{ml}$ & $5 \mathrm{mg} / \mathrm{ml}$ & $0,2 \mathrm{mg} / \mathrm{ml}$ \\
\hline Excipients & $\begin{array}{l}\text { Glycerol, Sorbitol, saccharin } \\
\text { sodium, xantan gum, aroma } \\
\text { lampone, sodio citrato, ac.citrico } \\
\text { monoidrato, nipagina, potassio } \\
\text { sorbato, acqua depurata }+ \\
\text { eccipienti del prodotto commerciale } \\
\text { (2 cpr su } 100 \mathrm{ml} \text { di preparato) }\end{array}$ & $\begin{array}{l}\text { Acqua depurata + eccipienti del } \\
\text { prodotto commerciale (100 cpr } \\
\text { su } 100 \mathrm{ml} \text { di preparato) }\end{array}$ & $\begin{array}{c}\text { Ora-sweet (Sorbitolo, saccarina } \\
\text { sodica, aroma lampone, sodio } \\
\text { fosfato, ac.citrico monoidrato, } \\
\text { nipagina, potassio sorbato, } \\
\text { acqua depurata) + eccipienti del } \\
\text { prodotto commerciale (4 cpr su } \\
100 \mathrm{ml} \text { di preparato) }\end{array}$ \\
\hline $\mathrm{pH}$ & $4,7-5,0$ & $7-7,3$ & $4,0-4,2$ \\
\hline Consistency & Viscous gel & White suspension & Fluid gel \\
\hline Note & $\begin{array}{l}\text { Suspension higly viscous, buffered, } \\
\text { preserved and aromatized }\end{array}$ & $\begin{array}{l}\text { Without preservatives, high } \\
\text { speed of sedimentation of } \\
\text { particles. }\end{array}$ & $\begin{array}{l}\text { Suspension viscous, buffered, } \\
\text { preserved and aromatized }\end{array}$ \\
\hline
\end{tabular}

varies from $0.1 \mathrm{mg} / \mathrm{ml}$ to $5 \mathrm{mg} / \mathrm{ml}$. The following Table 1 lists the main features and differences of formulations:

\section{MATERIALS AND METHODS}

Raw materilal was purchaused from different suppliers; Gliben $5 \mathrm{mg}$ from ABIOGEN Pharma, Glycerol from COGNIS OLEOCHEMICALS GMBH Germany, Sorbitol, Sodium Saccharine, Citric acid monohydrate, Sodium citrate, from Caesar \& Lorentz Gmbh Hilden (Germany), Xantan gum from Cargill Texturizing Solutions (Germany), raspberry aroma liquid from ESPERIS, Sodium Nipagine from Sharon
Laboratoires (Israel), Potassium sorbate from Shandong Reipu Chemicals Co.Ltd (China), Water from Ramini (Italy), Ora sweet SF from Paddock (USA).

\section{Method of Preparation of Formulation A}

1. Reduce medicaments in very fine powder, possibly micronisers. The particle size of powders greatly influences the absorption of active ingredients;

2. Disposing of freshly boiled water will take about $25 \mathrm{ml}$ and loose preservatives, system buffer and sodium saccharin; 
3. Aside prepare the mucilage dispersing the xanthan gum and dust of the tablets in a mortar where we previously mixed glycerol and sorbitol;

4. Add the mucilage obtained and small portions of the aqueous solution and bring to volume with the remaining water in a graduated container.

5. Packaging and labelling.

\section{Method of Preparation of Formulation B}

For staging have proposed the following procedure:

1. In the mortar accurately pulverize 150 tablets to obtain a powder with a uniform particle size;

2. Add to subsequent rates $140 \mathrm{ml}$ of water for injections wetting the dust initially with a little water to avoid lumps and diluting then gradually the mass obtained with the gradual homogenization;

3. Withdraw twice $50 \mathrm{ml}$ of suspension with a syringe and transfer in a dark glass bottle, using a new container or clean and reuse one previously used for the same preparation;

4. Pick up the remaining $50 \mathrm{ml}$ syringe;

5. Tap the syringe with protective red cover;

6. Labeled vial and syringe;

7. Noted on recipe the details of the preparation (batch and expiry Euglucon or Gliben $5 \mathrm{mg}$ used). On the label we recommend shake before use, make sure the powder is suspended and suspension has validity of one month.

\section{Method of Preparation of Formulation C}

1. Calculate the quantity of each component necessary for the preparation;

2. Crush glibenclamide tablets using possibly a micronizer, in order to reduce the size of the particles below 100 microns and use a sieve;

3. Add in a mortar a portion of the Ora-Sweet SF and mix with the dust; then put the suspension obtained a graduated container; add in the mortar another portion of Ora-Sweet SF. In this way we make a wash of instruments (mortar and pestle). Finally we make up to volume in that graduated container and continue mixing.
4. Packaging and label.

\section{Analytical Methods}

The analytical method for the quantitative determination of glibenclamide was developed by the Regional Quality Control Laboratory(RQCL) from data in the literature (2-6).

The chemicals (Water, Methanol and Formic Acid 96\%, all LC-MS grade), were obtained from SigmaAldrich (St. Louis, Missouri, U.S.).

Quantitative determination of glibenclamide was performed with HPLC-MS/MS analytical technique (High Pressure Liquid Chromatography - Mass Spectrometry) by HPLC [10-11], Agilent Technologies 1100 series, and detected by means of a 6410 triple quadrupole mass spectrometer (Santa Clara, California, USA) by monitoring all selective ions. The drug were detected after Electro-Spray Ionization (ESI) in positive mode by Multiple Reaction Monitoring (MRM) [12-15]. The limit of detection (LOD) were 0.5 pg. The glibenclamide in extemporaneous formulations samples, prepared as described above in "Sample manipulation and dilution in order to the quantitative determination", was quantified using the equation obtained for each session analysis with four scalar concentrations of standard solutions.

The Table 2 lists analytical parameters of the method adopted. The LOQ (Limit of Quantification) of the method on the tested range of linearity was $2.5 \mathrm{pg}$. The linearity was studied in a range of concentrations between $0,0005 \mu \mathrm{g} / \mathrm{ml}$ to $50 \mu \mathrm{g} / \mathrm{ml}$. The concentrations between $0,05 \mu \mathrm{g} / \mathrm{ml}$ and $2 \mu \mathrm{g} / \mathrm{ml}$ show a linearity with $r$ $=0.9997$.

Precision studies have been estimated by quantification of three scalar concentrations $(0.3,0.6$ and $0.9 \mathrm{\mu g} / \mathrm{ml}$ ) with intra-day test (verifying repeatability) and inter-day (intermediate precision study). The CV has been consistently lower than $5 \%$.

\section{Stability Study}

Three samples of formulation A, B and C were prepared. All the samples were tested at time zero with the following described and then each sample was divided into two homogeneous portions one of which stored at room temperature and the other refrigerate at $2-8^{\circ} \mathrm{C}$.

All the bottles were manipulated in the times below indicated to get the solution to the required 
Table 2: Analitycal Parameters

\begin{tabular}{|c|c|}
\hline Parameter & Value \\
\hline Mode & MRM \\
\hline Sample transfer & ESI \\
\hline Polarity & Positive \\
\hline Parent ion $(\mathrm{M}+\mathrm{H})+$ & 494,2 \\
\hline Product ions & $369,1-359,1-169,1$ \\
\hline Fragmentor & 130 \\
\hline Collision Energy & 8 \\
\hline Gas Temperature & $320^{\wedge} \mathrm{C}$ \\
\hline Drying gas flow & $6,5 \mathrm{~L} / \mathrm{min}$ \\
\hline Nebulizer & $28 \mathrm{psi}$ \\
\hline Capillary voltage & $4000 \mathrm{~V}$ \\
\hline Injection volume & 3-5 ul \\
\hline Analytical column & Gemini C18 5um 150mm RP18 Phenomenex \\
\hline Flow rate & $0.4 \mathrm{ml} / \mathrm{min}$ \\
\hline Mobile phase & Formic acid $0.1 \%$ in water : $\mathrm{MeOH} 30: 70(\mathrm{v} / \mathrm{v})$ \\
\hline Gradient & none \\
\hline Column temperature & $30^{\circ} \mathrm{C}$ \\
\hline UV detection & $230 \mathrm{~nm}$ \\
\hline Run time & $6 \min$ \\
\hline Retention time & $3,2 \min$ \\
\hline
\end{tabular}

concentration $(0.5 \mu \mathrm{g} / \mathrm{ml})$ in accordance with the conditions described above, at the times 0-3-7-14-2130-45-60-90 days. Samples diluted to $0.5 \mu \mathrm{g} / \mathrm{ml}$ were analyzed using HPLC-MS/MS in duplicate.

\section{Sample Manipulation and Dilution in Order to the Quantitative Determination}

The bottles were signed: A-room temperature, Arefrigerated; B- room temperature, B-refrigerated; Croom temperature, C-refrigerated.

Before dilution are handled as follows:

a. Remove dropper cap after discharge and replacement with a screw cap.

b. Shaking vigorously for 10 seconds and then to overthrow 10 times.

c. Immediate transfer in a tube by $13 \mathrm{ml}$ for $\mathrm{pH}$ measurement with potentiometer and universal pH map 1-14 (only the first time at time "zero").

d. Reunion of the taken portion for $\mathrm{pH}$ measurement with the rest of the suspension.
Dividing of the sample into two portions by around $50 \mathrm{ml}$ in amber bottles; one of which is kept refrigerated $\left(2-8^{\circ} \mathrm{C}\right)$ and the other at room temperature $\left(22-25^{\circ} \mathrm{C}\right)$.

\section{Dilution of the Three Formulations}

Before arranged dilution in order to bring all three formulations at a concentration suitable for quantitative analysis in HPLC-MS/MS, each sample is shaked as indicated above in subparagraph b. Subsequently operations differ in three series:

\section{A-Formulation $(0.1 \mathrm{mg} / \mathrm{ml})$}

Withdraw from the center of the mass with a disposable Pasteur pipette, of a quantity sufficient for the analytical balance to weigh $0.5 \mathrm{~g}$ of the suspension (directly on the tube from $13 \mathrm{ml}$ );

Add $9.5 \mathrm{ml}$ of methanol and shake on vortex for 30 seconds;

Wait 15 minutes and new shaking on vortex for 10 seconds; 
Withdraw $0,1 \mathrm{ml}$ of the dilute solution make up to 1 $\mathrm{ml}$ with methanol. This diluted solution has a concentration of $0.5 \mu \mathrm{g} / \mathrm{ml}$.

\section{B-Formulation (5 mg/ml)}

Withdraw from the center of mass with a Gilson calibrated pipette $0,5 \mathrm{ml}$ of suspension that are deposited in a test tube by $13 \mathrm{ml}$ together with the disposable tip;

Add $4.5 \mathrm{ml}$ of methanol and shake on vortex for 30 seconds;

Wait 15 minutes and new shaking on vortex for 10 seconds;

Withdraw with graduated pipette $0.1 \mathrm{ml}$ of the dilute solution make up to $10 \mathrm{ml}$ with methanol. This diluted solution has a concentration of $5 \mu \mathrm{g} / \mathrm{ml}$;

Shake on vortex for 10 seconds;

Withdraw with graduated pipette $0,1 \mathrm{ml}$ of the diluted solution make up to $1 \mathrm{ml}$ with methanol. This diluted solution has a concentration of $0.5 \mu \mathrm{g} / \mathrm{ml}$.

\section{C-Formulation $(0.2 \mathrm{mg} / \mathrm{ml})$}

Withdraw from the center of mass with a disposable Pasteur pipette of a quantity sufficient for the analytical balance to weigh $0.5 \mathrm{~g}$ of the suspension (directly on the tube from $13 \mathrm{ml}$ );
Add $9.5 \mathrm{ml}$ of methanol and shake on vortex for 30 seconds;

Wait 15 minutes and new shaking on vortex for 10 seconds;

Withdraw with syringe Hamilton $40 \mu \mathrm{l}$ of dilute solution making up to $800 \mu \mathrm{l}$ with methanol. This diluted solution has a concentration of $0.5 \mu \mathrm{g} / \mathrm{ml}$.

\section{Preparation of Standard Reference}

Methanol is chosen as a solvent since glibenclamide is readily soluble in organic solvents.

Glibenclamide as purified active substance is not commercially available on market of pharmaceutical grade substances; for these reason we used to extract the drug from the marketed medicinal product used for the study. The procedure for the extraction was the following: 1 tablet of $5 \mathrm{mg}$ of speciality GlibenR is finely shredded on mortar, adding $10 \mathrm{ml}$ of methanol in the mortar, the suspension is amalgamated, poured into the graduated cylinder, wash repeatedly mortar and pestle with 5-8 $\mathrm{ml}$ of methanol for five times, make up to $50 \mathrm{ml}$ with methanol. The solution is shaked and one part is filtered on 0.22 um filters. The filtered solution is further diluted to $0.5 \mathrm{ug} / \mathrm{ml}$; divided into 10 fractions of $1 \mathrm{ml}$ and put to $-20^{\circ} \mathrm{C}$. In each analysis session, at the times specified below, a fraction was used as external reference standard for the quantification of the active ingredient in the samples analyzed.

Table 3: Stability of Glibenclamide Suspensions Stored at Room Temperature

\begin{tabular}{|c|c|c|c|c|c|c|c|c|c|}
\hline Formulation & $\begin{array}{c}\text { Initial drug } \\
\text { concentration }\end{array}$ & $\begin{array}{c}\text { Day 3 } \\
\mathbf{m g} / \mathbf{m l}\end{array}$ & $\begin{array}{c}\text { Day } \mathbf{7} \\
\mathbf{m g} / \mathbf{m l}\end{array}$ & $\begin{array}{c}\text { Day 14 } \\
\mathbf{m g} / \mathbf{m l}\end{array}$ & $\begin{array}{c}\text { Day 21 } \\
\mathbf{m g} / \mathbf{m l}\end{array}$ & $\begin{array}{c}\text { Day 30 } \\
\mathbf{m g} / \mathbf{m l}\end{array}$ & $\begin{array}{c}\text { Day 45 } \\
\mathbf{m g} / \mathbf{m l}\end{array}$ & $\begin{array}{c}\text { Day 60 } \\
\mathbf{m g} / \mathbf{m l}\end{array}$ & $\begin{array}{c}\text { Day 90 } \\
\mathbf{m g} / \mathbf{m l}\end{array}$ \\
\hline \hline $\mathrm{A}$ & $0.1 \mathrm{mg} / \mathrm{ml}$ & 0.1006 & 0.1008 & 0.1038 & 0.1051 & 0.1044 & 0.1051 & 0.1060 & 0.1066 \\
\hline $\mathrm{B}$ & $5 \mathrm{mg} / \mathrm{ml}$ & 5.0438 & 5.0041 & 4.9229 & 4.9060 & 4.9468 & 4.9807 & 4.8964 & 4.8999 \\
\hline $\mathrm{C}$ & $0.2 \mathrm{mg} / \mathrm{ml}$ & 0.2049 & 0.1959 & 0.1983 & 0.1998 & 0.1935 & 0.1940 & 0.1891 & 0.1904 \\
\hline
\end{tabular}

Table 4: Stability of Glibenclamide Suspensions Stored at $2-8^{\circ} \mathrm{C}$

\begin{tabular}{|c|c|c|c|c|c|c|c|c|c|}
\hline Formulation & $\begin{array}{l}\text { Initial drug } \\
\text { concentration }\end{array}$ & $\begin{array}{l}\text { Day } 3 \\
\mathrm{mg} / \mathrm{ml}\end{array}$ & $\begin{array}{l}\text { Day } 7 \\
\mathrm{mg} / \mathrm{ml}\end{array}$ & $\begin{array}{l}\text { Day } 14 \\
\mathrm{mg} / \mathrm{ml}\end{array}$ & $\begin{array}{l}\text { Day } 21 \\
\mathrm{mg} / \mathrm{ml}\end{array}$ & $\begin{array}{l}\text { Day } 30 \\
\mathrm{mg} / \mathrm{ml}\end{array}$ & $\begin{array}{l}\text { Day } 45 \\
\mathrm{mg} / \mathrm{ml}\end{array}$ & $\begin{array}{l}\text { Day } 60 \\
\mathrm{mg} / \mathrm{ml}\end{array}$ & $\begin{array}{l}\text { Day } 90 \\
\mathrm{mg} / \mathrm{ml}\end{array}$ \\
\hline$A$ & $0.1 \mathrm{mg} / \mathrm{ml}$ & 0.1028 & 0.1028 & 0.1050 & 0.1051 & 0.1055 & 0.1063 & 0.1074 & 0.1082 \\
\hline B & $5 \mathrm{mg} / \mathrm{ml}$ & 4.9157 & 4.9983 & 4.9419 & 5.0160 & 5.0018 & 4.9755 & 4.9389 & 4.9537 \\
\hline $\mathrm{C}$ & $0.2 \mathrm{mg} / \mathrm{ml}$ & 0.1382 & 0.2558 & 0.1985 & 0.2009 & 0.1960 & 0.1933 & 0.1917 & 0.1910 \\
\hline
\end{tabular}


Table 5: Statistical Data of Stability Assay at Room and Refrigerated Temperature

\begin{tabular}{|c|c|c|c|c|c|}
\hline Formulation & $\begin{array}{c}\text { Nominal } \\
\text { concentration }\end{array}$ & average & SD & variance & $\begin{array}{c}\text { F test } \\
\text { (vs room temp) }\end{array}$ \\
\hline A room temp & $0.1 \mathrm{mg} / \mathrm{ml}$ & 0.1038 & 0.0021 & 0.0000005 & - \\
\hline A refrigerated & $0.1 \mathrm{mg} / \mathrm{ml}$ & 0.1050 & 0.0020 & 0.000004 & 0.8640 (N.S.) \\
\hline B room temp & $5 \mathrm{mg} / \mathrm{ml}$ & 4.9545 & 0.0526 & 0.002773 & - \\
\hline $\mathrm{B}$ refrigerated & $5 \mathrm{mg} / \mathrm{ml}$ & 4.9702 & 0.0342 & 0.001169 & 0.2434 (N.S.) \\
\hline C room temp & $0.2 \mathrm{mg} / \mathrm{ml}$ & 0.1962 & 0.0051 & 0.000026 & - \\
\hline C refrigerated & $0.2 \mathrm{mg} / \mathrm{ml}$ & 0.1976 & 0.0049 & 0.000024 & 0.9307 (N.S.) \\
\hline
\end{tabular}

\section{RESULTS AND DISCUSSION}

The study allows to evaluate the stability in time of formulations of glibenclamide, with two modes of preservation, from three different formulations.

Stability data are encouraging. They document that all the analyzed formulations are stable for at least 90 days as reported in Tables $\mathbf{3}$ and $\mathbf{4}$.
We reported the percentual variation in Tables 6, 7 and 8 .

The statistical analysis shows that the stability is acceptable for all three formulation.

As shown in Table 5, there is no significant difference between the samples stored at room temperature or at $2-8{ }^{\circ} \mathrm{C}$ within each series.

Table 6: Formulation A

\begin{tabular}{|c|c|c|}
\hline nominal concentration $\mathbf{0 . 1} \mathbf{m g} / \mathbf{m l}$ & \multicolumn{2}{|c|}{ \% variation } \\
\hline Time (day) & Form.A room temp & 1,474 \\
\hline 0 & 1,474 & 2,850 \\
\hline 3 & 0,571 & 4,059 \\
\hline 7 & 0,792 & 5,009 \\
\hline 14 & 3,792 & 5,125 \\
\hline 21 & 5,081 & 5,452 \\
\hline 30 & 4,425 & 6,340 \\
\hline 45 & 5,056 & 7,378 \\
\hline 60 & 5,964 & 8,193 \\
\hline 90 & 6,607 & \\
\hline
\end{tabular}

Table 7: Formulation B

\begin{tabular}{|c|c|c|}
\hline nominal concentration $\mathbf{5 m g} / \mathbf{m l}$ & \multicolumn{2}{|c|}{ \% variation } \\
\hline Time (day) & Form.B room temp & $-0,298$ \\
\hline 0 & $-0,298$ & $-1,687$ \\
\hline 3 & 0,877 & $-0,034$ \\
\hline 7 & 0,082 & $-1,162$ \\
\hline 14 & $-1,543$ & 0,321 \\
\hline 21 & $-1,880$ & $-1,064$ \\
\hline 30 & $-1,064$ & $-0,489$ \\
\hline 45 & $-0,386$ & $-1,222$ \\
\hline 60 & $-2,071$ & $-0,926$ \\
\hline 90 & $-2,002$ & \\
\hline
\end{tabular}


Table 8: Formulation C

\begin{tabular}{|c|c|c|}
\hline nominal concentration $\mathbf{0 . 2 m g / m l ~}$ & \multicolumn{2}{|c|}{ Foriation } \\
\hline Time (day) & Form. C room temp refrig \\
\hline \hline 0 & 2,481 & 2,481 \\
\hline 3 & 0,827 & 0,874 \\
\hline 7 & $-0,827$ & $-0,732$ \\
\hline 14 & $-0,869$ & $-0,751$ \\
\hline 21 & $-0,093$ & 0,457 \\
\hline 30 & $-3,230$ & $-2,016$ \\
\hline 45 & $-3,007$ & $-3,341$ \\
\hline 60 & $-5,447$ & $-4,129$ \\
\hline 90 & $-4,815$ & $-4,481$ \\
\hline
\end{tabular}

Table 9: Statistical Data of Stability Assay for the Formulation A, B, C

\begin{tabular}{|c|c|c|c|c|}
\hline & \multicolumn{2}{|c|}{ Room temperature } & \multicolumn{2}{c|}{ Refrigerated 2-8 ${ }^{\circ} \mathbf{C}$} \\
\hline & T Test & $\boldsymbol{T}$ & Test \\
\hline \hline$A$ vs B & 4,3605 & $<0,002$ & 7,6028 & $<0,001$ \\
\hline$A$ vs $C$ & 3,4989 & $<0,005$ & 4,3171 & $<0,002$ \\
\hline$B$ vs $C$ & 1,0230 & N.S. & 0,7367 & N.S. \\
\hline
\end{tabular}

The stability study instead shows significant differences between the sample A and sample B or C regardless of the storage temperature (Table 9 ).

A-formulation, presents values on the rise in the days following the time "zero": this is not readily interpretable, since it assumes that the concentration can only diminish for effect of the degradation of the active substance and does not increase. However we must not forget that we analyze a suspension in a gel form and thickened. It is not to exclude the possibility that the viscosity of suspension can change over time, making the active ingredient more available for dissolution in methanol. Secondly it is possible that the solvent used for preparation of the active ingredient (methanol) is less efficient in the period immediately after preparation of more dense suspension $(A)$.

B-formulation, while presenting a better stability, is subject to risk of underdosing or overdosing because of strong dependence on the mode of agitation and withdrawal times after shaking the bottle.

Therefore, we hypothesize that at time "zero" the real concentration in A-formulation is at least equal to that observed in 90 days.
Refrigeration does not provide a significant improvement to the stability of the three formulations. The preservation of preparations in the refrigerator at $2-8^{\circ} \mathrm{C}$ ensures a reduction of microbial growth but does not affect the stability of galenic preparation.

Alternatively to the previous formulation that as we will see from the figures that follow shows to have major problems of physical stability, are proposed A and $B$ formulations that, despite having a different title of glibenclamide from the previous, are very stable.

\section{Suggestions and Proposals}

a. the B-formulation appears too concentrated and therefore unfit to administration in age groups where dosages are extremely low; moreover the sedimentation speed is such as make actually unsuitable the dose administered from time to time.

b. both $\mathrm{A}$ and $\mathrm{C}$-formulation are suitable for use in clinical practice. The $\mathrm{C}$ - formulation is more rapid setting using a base ready. The A solution is economically advantageous to the user. 

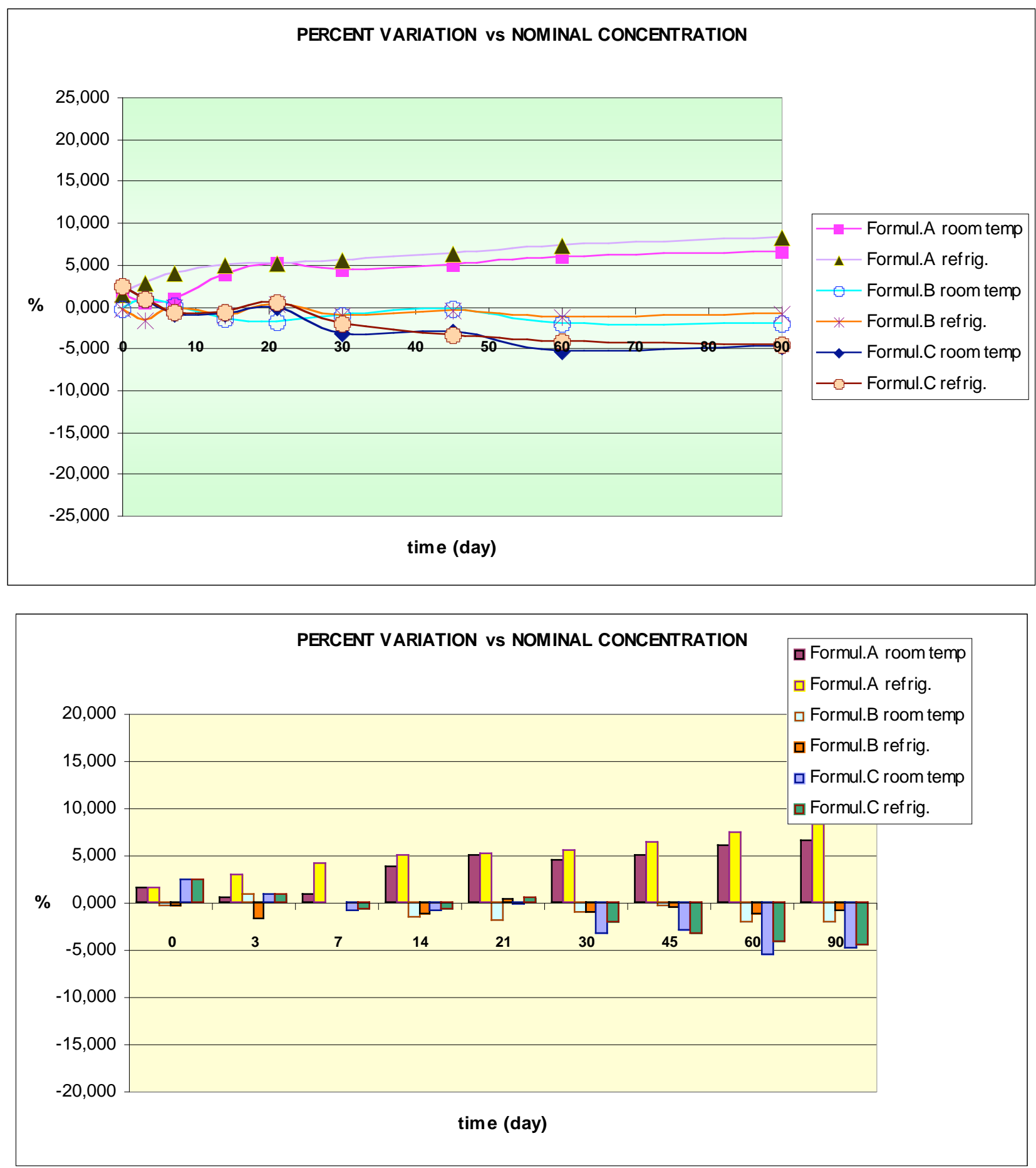

Figure 2: Percent variation vs nominal concentration.

\section{REFERENCES}

[1] Aydın BK, Bundak R, Baş F. Permanent neonatal diabetes mellitus: same mutation, different glycemic control with sulfonylurea therapy on long-term follow-up. J Clin Res Pediatr En docrinol 2012; 4(2): 107-10.

[2] Ooi HL, Ling L. Three cases of permanent neonatal diabetes mellitus: genotypes and management outcome. Singapore Med J 2012; 53(7): e142.

[3] Wambacha JA, Marshalla BA, Kosterb JC. Successful sulfonylurea treatment of an insulin-na"Ive neonate with diabetes mellitus due to a KCNJ11 mutation. Pediatric Diabetes 2010; 11: 286-88.

[4] Edghill EL, Flanagan SE, Ellard S. Permanent neonatal diabetes due to activating mutations in ABCC8 and KCNJ11. Rev Endocr Metab Disord 2010; 11: 193-98. http://dx.doi.org/10.1007/s11154-010-9149-x

[5] Meena R, Sarah F. Effective Treatment with oral Sulfonylureas in patients with diabetes due to sulfonylurea receptor 1 (SUR1) mutations. Diabetes Care 2008; 31(2). 
[6] Isabelle F, Martine V. Neonatal hyperglycaemia and abnormal development of the pancreas. Best Practice Res Clin Endocrinol Metab 2008; 22(1): 17-40. http://dx.doi.org/10.1016/j.beem.2007.08.003

[7] Masia R, Koster JC, Tumini S. An ATP-Binding Mutation (G334D) in KCNJ11 is associated with a sulfonylureainsensitive form of developmental delay, epilepsy, and neonatal diabetes. Diabetes 2007; 56. http://dx.doi.org/10.2337/db06-1275

[8] Ewan RP, Isabelle F. Switching from insulin to oral sulfonylureas in patients with diabetes due to kir6.2 mutations. N Engl J Med 2006; 355: 467-77. http://dx.doi.org/10.1056/NEJMoa061759

[9] Isabelle F, Philippe F. Neonatal hyperglycaemia and abnormal development of the pancreas. Best Practice Res Clin Endocrinol Metab 2008; 22(1): 17-40. http://dx.doi.org/10.1016/j.beem.2007.08.003

[10] The Merck Index, $12^{\text {th }}$ ed. Whitehouse Station, NJ, Budavari S 1996.

[11] Yao J, Shi Y-Q, Li Z-R. Development of a RP-HPLC method for screening potentially counterfeit anti-diabetic drugs. J Chromatography B 2007; 853: 254-9.

http://dx.doi.org/10.1016/j.jchromb.2007.03.022
[12] Naraharisetti SB, Kirby BJ, Hebert MF. Validation of a sensitive LC-MS assay for quantification of Glyburide and its metabolite 4-transhydroxy glyburide in plasma and urine: an OPRU Network study. J Chromatography B 2007; 853: 3441. http://dx.doi.org/10.1016/j.jchromb.2007.10.010

[13] Hamdam II, Bani Jaber AK, Abushoffa AM. Development and validation of a stability indicating capillary electophoresis method for the determination of metformin hydrochloride in tablets. J Pharm Biomedical Analysis 2010; 53: 1254-7. http://dx.doi.org/10.1016/j.jpba.2010.03.017

[14] Bansal G, Singh M, Jindal KC. Studies to characterize degradation products in glimepiride. J Pharm Biomedical Analysis 2008; 48: 788-95. http://dx.doi.org/10.1016/j.jpba.2008.08.003

[15] Bagagiolo S, Moretti V. La stabilità microbiologica dei preparati galenici per uso orale. It J Clinical Pharmacy 2008; 3: 288-9. 